\title{
Morphological and molecular characterisation of Steinernema hermaphroditum n. sp. (Nematoda: Steinernematidae), an entomopathogenic nematode from Indonesia, and its phylogenetic relationships with other members of the genus
}

\author{
S. Patricia STOCK ${ }^{1, *}$, Christine T. GRIFFIN ${ }^{2}$ and Rani CHAERANI ${ }^{3}$ \\ ${ }^{1}$ Department of Plant Pathology, University of Arizona, Forbes 204. 1140 E., South Campus Drive, \\ Tucson, AZ 85721-0036, USA \\ ${ }^{2}$ Department of Biology, National University of Ireland Maynooth, Maynooth, Co. Kildare, Ireland \\ ${ }^{3}$ BORIF, 3A Jalan Tentara Pelajar, Bogor 16114, Indonesia
}

Received: 16 February 2004; revised: 22 April 2004 Accepted for publication: 26 April 2004

\begin{abstract}
Summary - Steinernema hermaphroditum n. sp., a new entomopathogenic nematode isolated from soil samples in the Moluccan islands, Indonesia, is described. Morphological observations as well as biological evidence (cross-hybridisation studies) indicate the distinctness of $S$. hermaphroditum n. sp. from other Steinernema spp. This new species is characterised by the presence of hermaphrodites in the first adult generation. Key morphological diagnostic characters include: a digitate tail with a mucro and a glandular spermatheca filled with sperm in the first generation hermaphrodite; the value of D\%; the morphology of the male spicules and gubernaculum and the number and arrangement of the genital papillae; the values of $\mathrm{D} \%, \mathrm{E} \%$ and the pattern of the lateral field of the third-stage infective juvenile. Additionally, molecular evidence obtained from ITS rDNA RFLP profiles, 28S rDNA sequence analyses, and phylogenetic reconstruction provide further evidence to establish this nematode as a new species.
\end{abstract}

Keywords - description, hermaphroditism, molecular, phylogeny, taxonomy.

Entomopathogenic nematodes (EPN) in the family Steinernematidae Chitwood \& Chitwood are insect parasites capable of infecting a broad range of insect species. They have been used as biological control agents of insect pests in a variety of crops (Gaugler \& Kaya, 1990; Kaya \& Gaugler, 1993). The third-stage juvenile (IJ) is the only free-living stage of these nematodes and is commonly found in soil and epigeal habitats by baiting with live insects (Bedding \& Akhurst, 1975). The IJ enter a living host and release symbiotic bacteria of the genus Xenorhabdus Poinar \& Thomas. The bacteria kill the host and the developing nematodes feed on the insect cadaver and digested tissues. The nematodes go through two or more generations, producing new IJ which emerge into the soil as host resources are depleted.

The Steinernematidae currently comprises two genera, Steinernema Travassos, 1927 with more than 35 recognised species, and Neosteinernema Nguyen \& Smart,
1994, with only one species, N. longicurvicauda Nguyen $\&$ Smart, 1994. The most updated biogeographic account indicates that these nematodes have been isolated from all continents (except Antarctica) and almost all regions of the world (Hominick, 2002). The number of EPN surveys in tropical and subtropical regions has significantly increased during the last decade. Tropical southeast countries in Asia, such as Sri Lanka (Amarasinghe et al., 1994), Malaysia (Masson et al., 1996), Vietnam (Nguyen et al., 1999; Phan et al., 2001a, b) and Indonesia (Griffin et al., 2000), have been extensively surveyed for EPN. As a result, several new species have been recovered and described (Stock et al., 1998; Luc et al., 2000; Phan et al., 2001a, b).

In a survey conducted by Griffin et al. (2000) in Indonesia, several Steinernema isolates were isolated in many of the islands that comprise the Moluccan archipelago. The T87 strain, of which several isolates

\footnotetext{
*Corresponding author, e-mail: spstock@ag.arizona.edu
} 
were collected, mainly from the islands of Ambon and Seram, displayed an RFLP profile that clearly identified them as a Steinernema sp. The RFLP profile of this species most closely resembled that of $S$. longicaudum Shen \& Wang (Griffin et al., 2000). However, during cross-breeding studies of the T87 isolates, uniparental reproduction evidence was found. The presence of sperm in the reproductive tract of unmated first generation females indicated that the mode of reproduction of this species is by hermaphroditism (Griffin et al., 2001). According to this study, a single IJ of the T87 isolate can colonise an insect and produce progeny. Approximately $1 \%$ of the IJ developed into males and males were also present in the second adult generation, but at a very low level (1-6\%) (Griffin et al., 2001).

In addition to these observations, subsequent morphological studies and molecular characterisation based on sequence analysis from the large subunit (28S) of rDNA provided further evidence to support the T87 isolate as being a new Steinernema species. It is described and illustrated below.

\section{Materials and methods}

\section{ORIGIN AND PROPAGATION OF THE ISOLATES}

Isolates were recovered from soil samples under different vegetation covers (i.e., scrub and trees) along the coastal fringe of the islands of Seram (Kamal) and Ambon (Waai) in the Indonesian archipelago (Griffin et al., 2000).

Nematodes were propagated in last-instar larvae of the wax moth, Galleria mellonella (L.) at $28-30^{\circ} \mathrm{C}$. Emerging IJ were harvested in modified White traps following procedures described by Kaya and Stock (1997). Harvested IJ were washed three times by sedimentation in distilled water and stored in water at $20^{\circ} \mathrm{C}$.

\section{MORPHOLOGICAL CHARACTERISATION}

\section{Light microscopy studies}

Twenty specimens from each stage (adults and IJ) were randomly collected from ten $G$. mellonella cadavers. Nematodes were examined live or heat-relaxed in Ringer's solution at $60^{\circ} \mathrm{C}$. Nematodes were fixed in triethanolamine formalin (TAF) (Courtney et al., 1955) and processed to anhydrous glycerine for mounting (Seinhorst, 1959). Specimens were mounted on glass slides, the coverslip being supported by glass rods to avoid flattening. Observations were made from live and mounted specimens using an Olympus BX60 microscope equipped with differential interference contrast optics. Specimen measurements were made using Scion Image software (Frederick, MD, USA) calibrated with a stage micrometer. Selection of morphometric characters was done according to Hominick et al. (1997). Illustrations were prepared from digitised camera lucida images.

The following abbreviations have been used in the text or tables, $\mathrm{ABD}=$ anal or cloacal body diameter, $\mathrm{EP}=$ excretory pore position, ES = pharynx length, GS = $\mathrm{GuL} / \mathrm{SpL}, \mathrm{GuL}=$ gubernaculum length, $\mathrm{H}=$ hyaline tail length; $\mathrm{H} \%=\mathrm{H}$ as $\%$ of $\mathrm{TL} ; \mathrm{MBD}=$ maximum body diameter, $\mathrm{ML}=$ mucro length, $\mathrm{NR}=$ nerve ring position, ratio $\mathrm{a}=\mathrm{L} / \mathrm{MBD}$, ratio $\mathrm{b}=\mathrm{L} / \mathrm{ES}$, ratio $\mathrm{c}=\mathrm{L} / \mathrm{TL}, \mathrm{D} \%=$ $\mathrm{EP} / \mathrm{ES} \times 100, \mathrm{E} \%=\mathrm{EP} / \mathrm{TL} \times 100, \mathrm{SpL}=$ spicule length (measured along the curved median line), $\mathrm{StL}=$ stoma length, $\mathrm{StW}=$ stoma diameter, $\mathrm{SW}=\mathrm{SpL} / \mathrm{ABD}, \mathrm{TL}=$ tail length.

\section{Scanning electron microscopy studies}

Adults were dissected from G. mellonella larvae in Ringer's solution ( $\mathrm{pH}$ 7.3). They were rinsed three times for $5 \mathrm{~min}$ in Ringer's solution. Three-day-old IJ were rinsed for three times $15 \mathrm{~min}$ in $0.05 \% \mathrm{NaCl}$. All nematodes were relaxed and killed by heating in a waterbath $\left(60^{\circ} \mathrm{C}\right)$ for $2-3 \mathrm{~min}$ and were then fixed in $8 \%$ glutaraldehyde $-25 \%$ EM grade (diluted in Ringer) for $2 \mathrm{~h}$ at room temperature. Fixed nematodes were rinsed in distilled water three times, post-fixed in $\mathrm{OsO}_{4}$ for $1 \mathrm{~h}$, rinsed in distilled water again and dehydrated at $15 \mathrm{~min}$ intervals through 30, 50, 70, 90, 95 and 100\% ethanol. They were then critical point dried in liquid $\mathrm{CO}_{2}$, mounted on SEM stubs, coated with gold and scanned using an SES DS130 equipped with a digital image camera and Imagecap $1000^{\mathrm{TM}}$ software (Woodstock, GA, USA). An accelerating voltage of $15 \mathrm{kV}$ was used for all observations.

\section{HYBRIDISATION TESTS}

Reproductive compatibility of the new species was tested using the following Steinernema spp.: S. scarabaei Stock \& Koppenhöfer, 2003; S. longicaudum Shen \& Wang, 1992; and an unknown Steinernema sp. from Indonesia (isolate T29). Third-stage juveniles produced by first generation adults (either by amphimixis or parthenogenesis) were surface sterilised in $0.4 \%$ hyamine and washed five times in sterile distilled water. Single juveniles were transferred to hanging drops of haemolymph 
according to procedures described by Kaya and Stock (1997). A total of 20 pairs/nematode combination were established by transferring one male into a drop containing a morphological female once they could be differentiated for each of the tested combinations. Controls consisted of hanging drops with adults of the same species.

\section{MOLECULAR CHARACTERISATION AND PHYLOGENETIC ANALYSIS}

Molecular characterisation of the new species was done by analysis of large-subunit of ribosomal DNA (LSU or $28 \mathrm{~S}$ rDNA) sequences. An existing library of more that 30 Steinernema spp. was used for sequence comparisons and phylogenetic interpretation. Total genomic DNA isolation, PCR amplification (reaction, cycling conditions and primers) and sequence analysis followed protocols described by Stock et al. (2001).

Phylogenetic analysis (maximum parsimony analysis) of LSU sequences was conducted using PAUP* version 4.0 (Swofford, 2001) following criteria described by Stock et al. (2001). Ribosomal sequences for $S$. hermaphroditum n. sp. were deposited in GenBank under the accession number AY598358.

\section{Steinernema hermaphroditum* ${ }^{*}$. sp.} (Figs 1-3)

\section{Measurements}

See Table 1.

\section{DESCRIPTION}

\section{Hermaphrodite}

Body C-shaped when heat-relaxed. Cuticle smooth under light microscopy, but with fine transverse striae visible under SEM. Lateral field and phasmids inconspicuous. Head truncated to slightly round, continuous with body. Six lips united but with tips distinct, each bearing one labial papilla. Four cephalic papillae. Amphidial apertures small, located posterior to lateral labial papillae. Stoma reduced (cheilo, gymno- and stegostom vestigial), short and wide, with inconspicuous sclerotised walls. Pharynx set off from intestine, with a cylindrical procorpus, a nonvalvated and slightly swollen metacorpus, a distinct isthmus and a pyriform basal bulb containing reduced valve.

\footnotetext{
* The specific epithet is derived from the presence of hermaphrodites in the first adult generation.
}

Nerve-ring usually surrounding isthmus or anterior part of basal bulb. Excretory pore opening circular, located at posterior third of metacorpus, just anterior to nerve-ring. Ovaries opposed, reflexed in dorsal position; oviduct well developed; glandular spermatheca filled with spermatozoa; uterus in ventral position. Vagina short, with muscular walls. Vulva more or less median in position with protruding and asymmetric vulvar lips (anterior lip larger than the posterior one). Epiptygma absent. Tail digitate, mucro present in $60 \%$ of the examined specimens. Postanal swelling present.

\section{Male}

Cuticle, lip region, stoma and pharyngeal region as in first generation hermaphrodite. Body curved posteriorly, J-shaped when heat-relaxed. Single reflexed testis, consisting of germinal growth zone leading to seminal vesicle. Vas deferens with inconspicuous walls. Spicules paired, symmetrical, curved, with ochre-brown coloration. Manubrium rectangular, wider than long, calomus short, lamina wide with two ribs, rostrum present. Velum short, extending from rostrum to distal ventral opening. Gubernaculum boat-shaped in lateral view, $c a$ two thirds length of spicules. Cuneus long, needle-shaped, pointed posteriorly. Genital papillae numbering 21 (ten pairs and one single): six precloacal subventral pairs, one single ventral precloacal papilla (located between precloacal pairs 5 and 6), one subdorsal precloacal pair, one postcloacal subdorsal pair, one subventral postcloacal pair, one terminal postcloacal pair. Second generation males are similar to first generation males, except for body length and diameter, position of excretory pore (more anteriorly located in second generation), and size of spicules and gubernaculum.

\section{Female (second generation)}

Body C-shaped when heat-relaxed. Cuticle, lip region, stoma and pharyngeal region as in first generation hermaphrodite. Ovaries paired, opposed and reflexed in dorsal position; oviduct well developed; spermatheca absent; uterus in ventral position. Vagina short, with muscular walls. Vulva more or less median in position with nonprotruding or slightly protruding vulvar lips. Epiptygma absent. Tail round-conoid, without a mucro. Post-anal swelling present or absent.

\section{Third-stage infective juvenile}

Body slender, tapering regularly from base of pharynx to anterior end and from anus to terminus. Lip region 

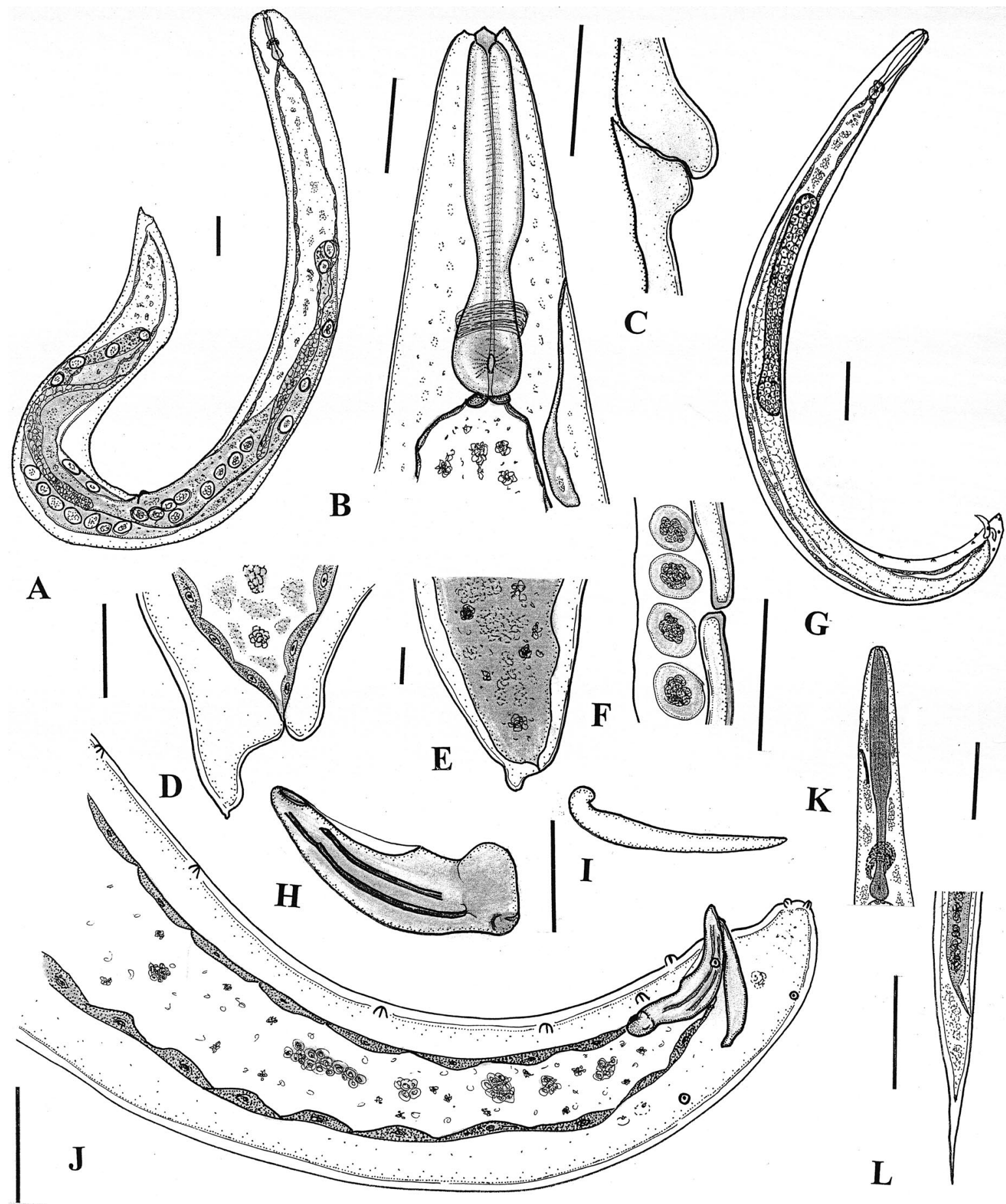

Fig. 1. Steinernema hermaphroditum n. sp. A-D: First-generation hermaphrodite. A: In toto; B: Anterior end, lateral view; C: Vulval lips, lateral view; D: Tail, lateral view. E, F: Second-generation female. E: Tail, lateral view; F: Vulval lips, lateral view - G-J: First generation male: G-J. G: In toto; H: Spicule, lateral view; I: Gubernaculum, lateral view; J: Tail, lateral view - K, L: Third-stage infective juvenile. K: Anterior end, lateral view; L: Tail, lateral view. (Scale bars: A, $G=100 \mu m ; B-E, J, K, L=50 \mu m ; F, H, I=25$ (m.) 

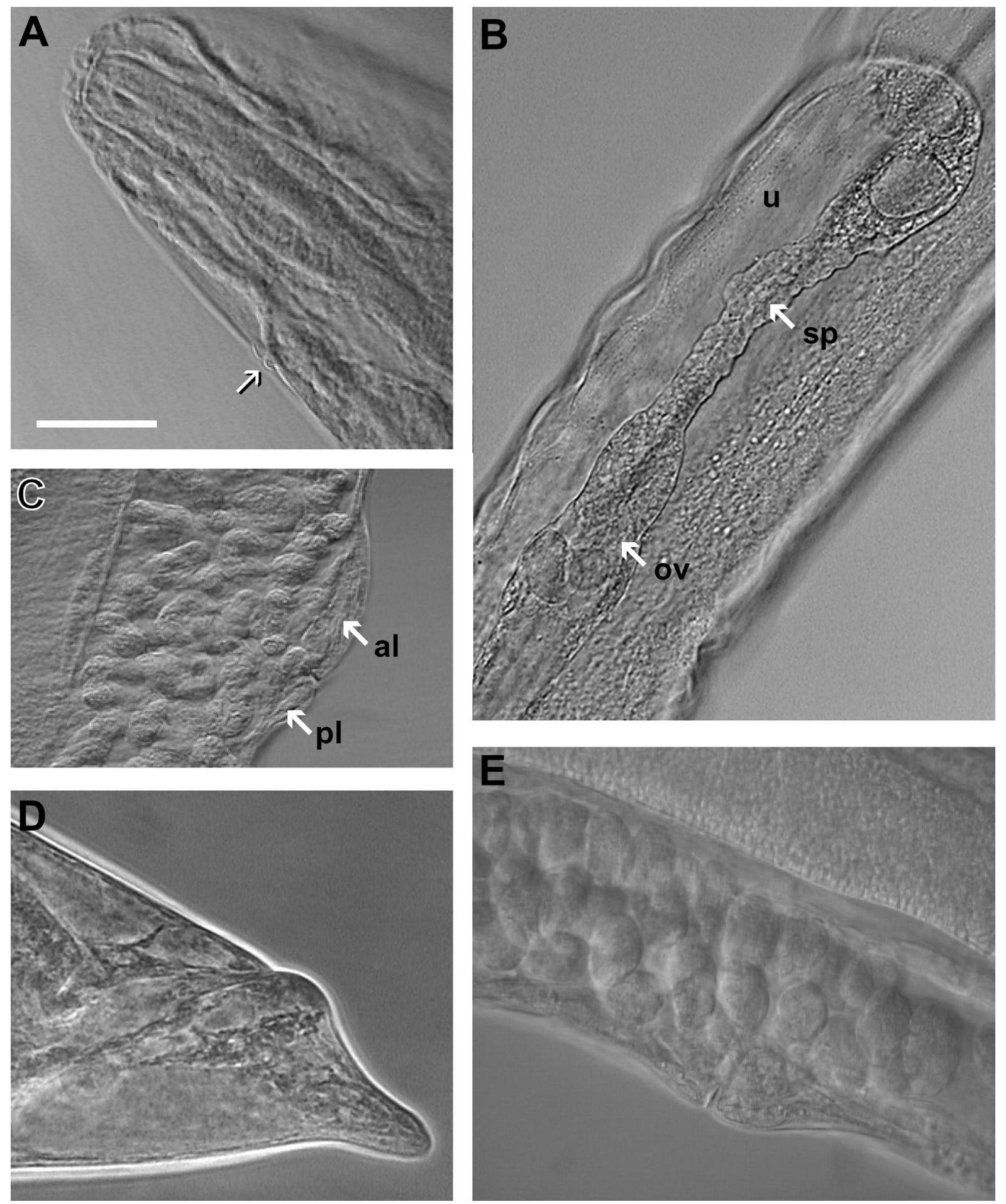

Fig. 2. Steinernema hermaphroditum n. sp. A-D: Hermaphrodite. Anterior end (lateral view) showing excretory pore location (arrow); B: Anterior part of reproductive (ov: ovary, sp: spermatheca, u: uterus); C: Vulva (al: anterior lip, pl: posterior lip); D: Tail (lateral view) - E: Second generation female vulva (lateral view). (All scales are based on the scale bar in $A$. $A=43 \mu m, B=17 \mu m, C=$ $10 \mu \mathrm{m}, D=32 \mu \mathrm{m}, E=15 \mu \mathrm{m}$.) 

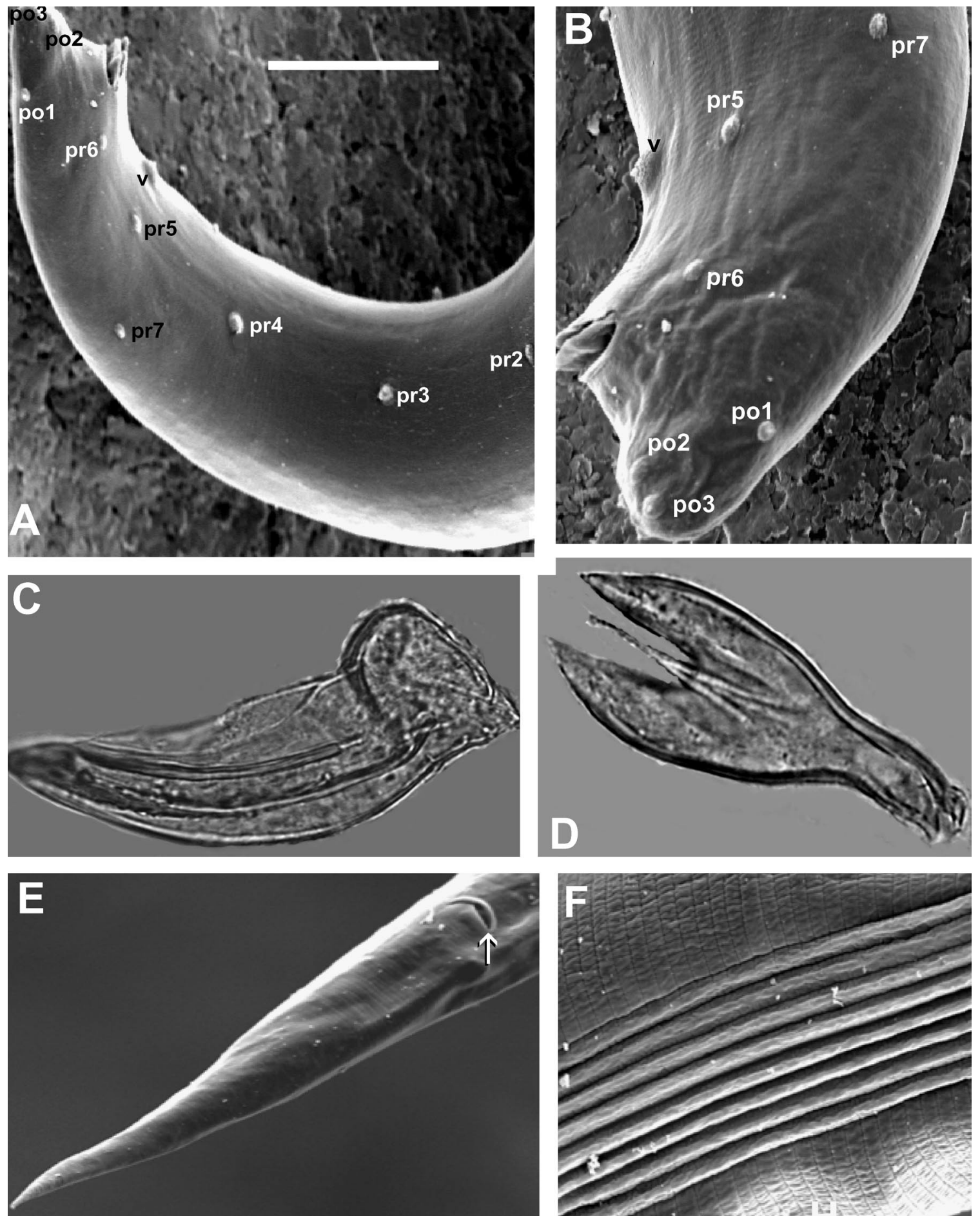

Fig. 3. Steinernema hermaphroditum n. sp. A-D: First generation male. A: Posterior end showing distribution of genital papillae (pr: precloacal, v: ventral, po: postcloacal; B: Distribution of genital papillae; C: Spicule (lateral view); D: Gubernaculum (dorsal view) E, F: Third-stage infective juvenile. E: Tail (ventral view) showing anus position (arrow); F: Lateral field pattern (midbody level). (All scales are based on the scale bar in $A . A=35 \mu \mathrm{m}, B=33 \mu \mathrm{m}, C=22 \mu \mathrm{m}, D=20 \mu \mathrm{m}, E=23 \mu \mathrm{m}, F=10 \mu \mathrm{m}$.) 
Table 1. Morphometrics of Steinernema hermaphroditum $n$. sp. All measurements are in $\mu m$ and are in the form: mean \pm standard deviation (range).

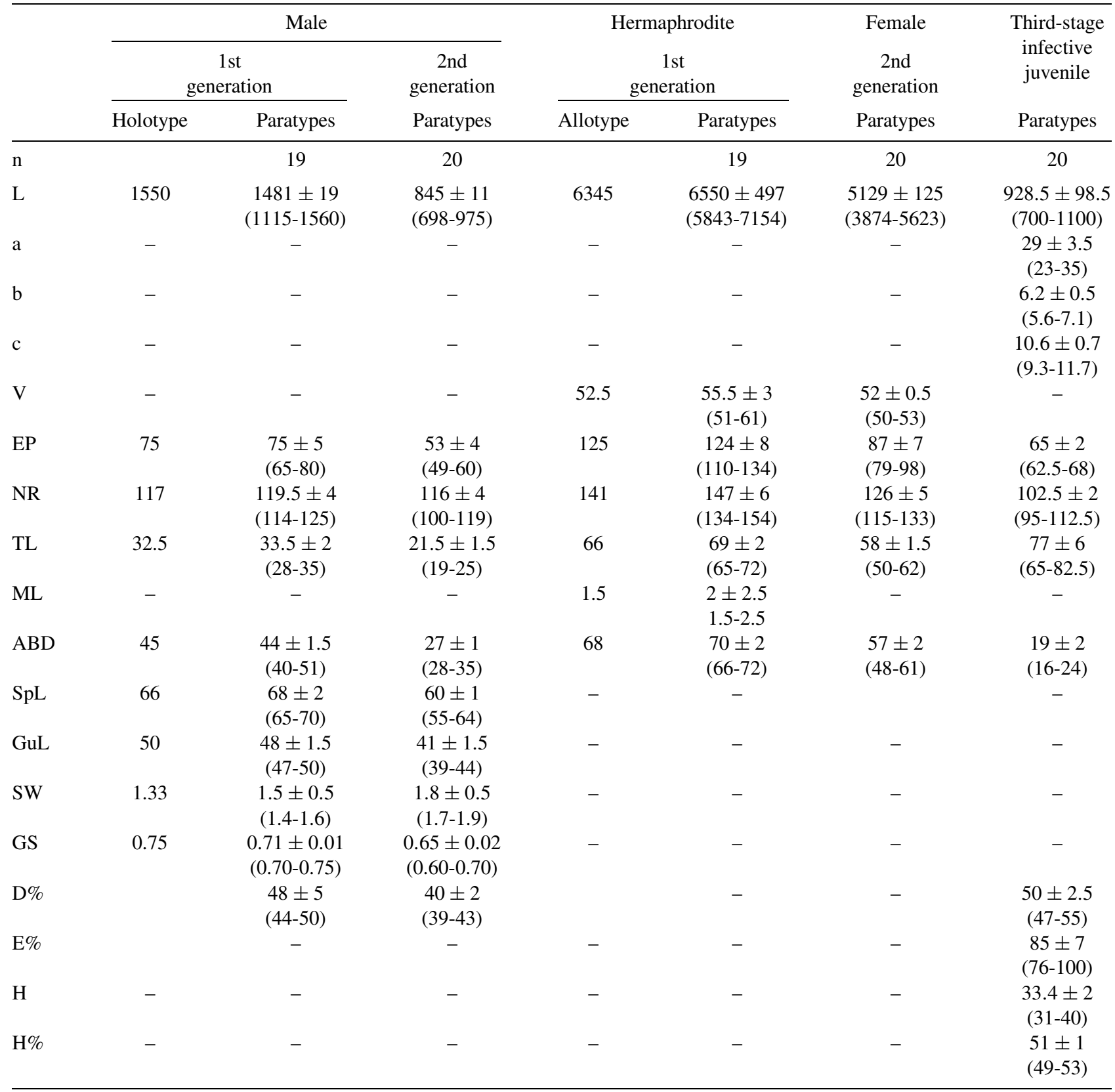

smooth; mouth closed. Cuticle with transverse striae; lateral field distinct with eight equidistant longitudinal ridges (i.e., nine lines) in mid-body region. Pharynx long, narrow. Nerve-ring located isthmus level. Excretory pore located $c a$ middle of pharynx. Basal bulb valvate.
Cardia present. Anterior portion of intestine with dorsally displaced pouch containing symbiotic bacteria. Lumen of intestine narrow; rectum long; anus distinct. Genital primordium evident. Tail conoid with pointed terminus. Hyaline comprising $c a$ half the tail length. 
Table 2. Comparison of morphometrics (mean and range) of third-stage infective juveniles and first generation males of Steinernema hermaphroditum $n$. sp. and other morphologically similar Steinernema spp. All measurements are in $\mu m$.

\begin{tabular}{|c|c|c|c|c|c|c|c|c|c|c|c|c|}
\hline \multirow[t]{2}{*}{ Species } & \multicolumn{6}{|c|}{ Third-stage infective juvenile } & \multicolumn{6}{|c|}{ First generation males } \\
\hline & $\mathrm{L}$ & MBD & EP & TL & $\mathrm{D} \%$ & $\mathrm{E} \%$ & $\mathrm{LF}$ & SPL & GUL & SW & $\mathrm{D} \%$ & M \\
\hline $\begin{array}{l}\text { S. hermaphroditum } \\
\text { n. sp. }\end{array}$ & $\begin{array}{c}928.5 \\
(700-955)\end{array}$ & $\begin{array}{c}28.5 \\
(25-32.5)\end{array}$ & $\begin{array}{c}65 \\
(62.5-68)\end{array}$ & $\begin{array}{c}77 \\
(65-82.5)\end{array}$ & $\begin{array}{c}50 \\
(47-55)\end{array}$ & $\begin{array}{c}85 \\
(76-100)\end{array}$ & 8 & $\begin{array}{c}68 \\
(65-70)\end{array}$ & $\begin{array}{c}48 \\
(47-50)\end{array}$ & $\begin{array}{c}1.5 \\
(1.4-1.6)\end{array}$ & $\begin{array}{c}48 \\
(44-50)\end{array}$ & A \\
\hline S. feltiae 1 & $\begin{array}{c}849 \\
(736-950)\end{array}$ & $\begin{array}{c}26 \\
(22-29)\end{array}$ & $\begin{array}{c}62 \\
(53-67)\end{array}$ & $\begin{array}{c}81 \\
(70-92)\end{array}$ & $\begin{array}{c}45 \\
(42-51)\end{array}$ & $\begin{array}{c}78 \\
(69-86)\end{array}$ & 8 & $\begin{array}{c}70 \\
(65-77)\end{array}$ & $\begin{array}{c}41 \\
(34-47)\end{array}$ & $\begin{array}{c}1.13 \\
(0.99-1.3)\end{array}$ & $\begin{array}{r}60 \\
\text { NA }\end{array}$ & $\mathrm{P}$ \\
\hline S. thanhi ${ }^{2}$ & $\begin{array}{c}851 \\
(720-960)\end{array}$ & $\begin{array}{c}31 \\
(27-39)\end{array}$ & $\begin{array}{c}75 \\
(68-84)\end{array}$ & $\begin{array}{c}63 \\
(52-72)\end{array}$ & $\begin{array}{c}58 \\
(52-67)\end{array}$ & $\begin{array}{c}119 \\
(101-138)\end{array}$ & 8 & $\begin{array}{c}72 \\
(67-78)\end{array}$ & $\begin{array}{c}49 \\
(40-56)\end{array}$ & $\begin{array}{c}1.8 \\
(1.5-2.1)\end{array}$ & $\begin{array}{c}73 \\
(64-82)\end{array}$ & A \\
\hline S. neocurtillae ${ }^{3}$ & $\begin{array}{c}885 \\
(741-988)\end{array}$ & $\begin{array}{c}34 \\
(28-42)\end{array}$ & $\begin{array}{c}18 \\
(14-22)\end{array}$ & $\begin{array}{c}80 \\
(64-97)\end{array}$ & $\begin{array}{c}12 \\
(10-15)\end{array}$ & $\begin{array}{c}23 \\
(18-30)\end{array}$ & 6 & $\begin{array}{c}58 \\
(52-64)\end{array}$ & $\begin{array}{c}52 \\
(44-59)\end{array}$ & $\begin{array}{c}1.43 \\
(1.18-1.64)\end{array}$ & $\begin{array}{c}19 \\
(13.26)\end{array}$ & $\mathrm{P}$ \\
\hline S. karii $^{4}$ & $\begin{array}{c}932 \\
(876-982)\end{array}$ & $\begin{array}{c}33 \\
(31-35)\end{array}$ & $\begin{array}{c}74 \\
(68-80)\end{array}$ & $\begin{array}{c}74 \\
(64-80)\end{array}$ & $\begin{array}{l}57 \\
\text { NA }\end{array}$ & $\begin{array}{l}96 \\
\text { NA }\end{array}$ & 8 & $\begin{array}{c}83 \\
(73-91)\end{array}$ & $\begin{array}{c}57 \\
(42-64)\end{array}$ & NA & $\begin{array}{c}66 \\
(57-78)\end{array}$ & A \\
\hline S. kraussei ${ }^{5}$ & $\begin{array}{c}957 \\
(797-1102)\end{array}$ & $\begin{array}{c}33 \\
(30-36)\end{array}$ & $\begin{array}{c}63 \\
(50-66)\end{array}$ & $\begin{array}{c}79 \\
(63-86)\end{array}$ & $\begin{array}{l}47 \\
\text { NA }\end{array}$ & $\begin{array}{r}80 \\
\mathrm{NA}\end{array}$ & 8 & $\begin{array}{c}55 \\
(52-57)\end{array}$ & $\begin{array}{c}33 \\
(23-38)\end{array}$ & $\begin{array}{l}1.10 \\
\text { NA }\end{array}$ & $\begin{array}{r}53 \\
\mathrm{NA}\end{array}$ & $\mathrm{P}$ \\
\hline S. oregonense 6 & $\begin{array}{c}980 \\
(820-1110)\end{array}$ & $\begin{array}{c}34 \\
(28-38)\end{array}$ & $\begin{array}{c}66 \\
(60-72)\end{array}$ & $\begin{array}{c}70 \\
(64-78)\end{array}$ & $\begin{array}{c}50 \\
(40-60)\end{array}$ & $\begin{array}{c}100 \\
(90-110)\end{array}$ & $6-8$ & $\begin{array}{c}71 \\
(65-73)\end{array}$ & $\begin{array}{c}56 \\
(52-59)\end{array}$ & $\begin{array}{l}1.51 \\
\text { NA }\end{array}$ & $\begin{array}{c}73 \\
(64-75)\end{array}$ & A \\
\hline S. loci ${ }^{2}$ & $\begin{array}{c}986 \\
(896-1072)\end{array}$ & $\begin{array}{c}37 \\
(30-45)\end{array}$ & $\begin{array}{c}80 \\
(71-86)\end{array}$ & $\begin{array}{c}75 \\
(66-83)\end{array}$ & $\begin{array}{c}57 \\
(52-63)\end{array}$ & $\begin{array}{c}107 \\
(94-120)\end{array}$ & 8 & $\begin{array}{c}71 \\
(60-80)\end{array}$ & $\begin{array}{c}46 \\
(40-52)\end{array}$ & $\begin{array}{c}1.9 \\
(1.7-2.1)\end{array}$ & $\begin{array}{c}73 \\
(61-80)\end{array}$ & A \\
\hline S. scarabaei ${ }^{7}$ & $\begin{array}{c}918 \\
(890-956)\end{array}$ & $\begin{array}{c}31 \\
(25-37)\end{array}$ & $\begin{array}{c}77 \\
(72-81.5)\end{array}$ & $\begin{array}{c}76 \\
(71-80)\end{array}$ & $\begin{array}{c}60 \\
(50-65)\end{array}$ & $\begin{array}{c}100 \\
(90-110)\end{array}$ & 8 & $\begin{array}{c}74 \\
(63-79)\end{array}$ & $\begin{array}{c}42 \\
(33-47)\end{array}$ & $\begin{array}{c}1.7 \\
(1.5-2.0)\end{array}$ & $\begin{array}{c}64 \\
(51-75)\end{array}$ & A \\
\hline
\end{tabular}

A: absent; LF: lateral field; M: mucro; NA: not available; P: present.

${ }^{1}$ after Poinar, 1990; ${ }^{2}$ after Phan et al., 2001a; ${ }^{3}$ after Nguyen \& Smart, 1992; ${ }^{4}$ after Waturu et al., 1997; ${ }^{5}$ after Mráček et al., 1994;

6 after Liu \& Berry, 1996; ${ }^{7}$ after Stock \& Koppenhöfer, 2003.

\section{TYPE HOST AND LOCALITY}

Host unknown in nature as material collected from bait-insect (G. mellonella larvae). The type isolate was recovered from scrubs and trees along the coastal strip of Kamal, Seram island, Indonesia (Griffin et al., 2000).

\section{OTHER LOCALITIES}

Banana/herbs and grass/herbs/coconut habitats in Waai, Ambon island, Indonesia (Griffin et al., 2000).

\section{TYPE MATERIAL}

Holotype male second generation, allotype hermaphrodite first generation, five paratype hermaphrodites first generation, five paratype second generation females, four paratype second generation males, five paratype third stage infective juveniles deposited in the University of California Nematode Collection, Davis, CA, USA; five paratype first generation males, five paratype first generation females; five paratype third-stage infective juveniles deposited in USDA Nematode Collection, Beltsville, MD, USA.

\section{HYBRIDISATION TESTS}

Attempts to cross-hybridise $S$. hermaphroditum sp. n. with S. scarabaei, S. longicaudum and Steinernema sp. (T29 isolate) yielded no progeny. Control crosses using individuals of the same species produced viable offspring. Only $60 \%$ of the drops (12 out of 20) with couples of $S$. hermaphroditum $\mathrm{n}$. sp. produced progeny.

\section{MOLECULAR CHARACTERISATION AND PHYLOGENETIC RELATIONSHIPS}

Maximum parsimony (MP) analysis of LSU sequence data yielded 371 parsimony informative characters and produced two most parsimonious trees with a tree length of 1080 steps $(\mathrm{CI}=0.60)$. A strict consensus $(50 \%$ majority-rule) tree with the corresponding bootstrap values is presented in Figure 4. 


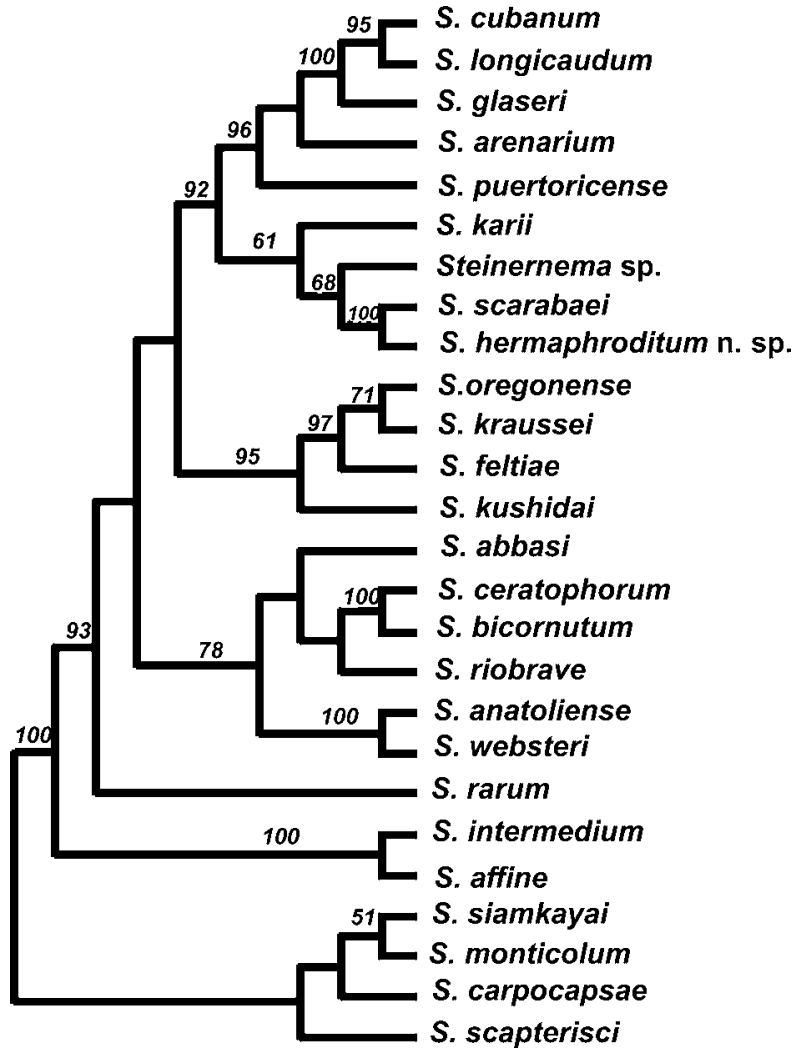

Fig. 4. Evidence of large subunit (LSU) ribosomal DNA lineage independence for Steinernema hermaphroditum n. sp. based on maximum parsimony analysis. Numbers in bold refer to bootstrap values.

Steinernema hermaphroditum n. sp. was placed in a clade that includes long-IJ Steinernema species also known as the glaseri-group. This clade comprises $S$. glaseri (Steiner, 1929); S. arenarium (Artyukhovsky, 1967); S. puertoricense Román \& Figueroa, 1994; S. cubanum Mráček, Hernandez \& Boemare, 1994; S. longicaudum; S. karii Waturu, Hunt \& Reid, 1997; S. scarabaei, and two unidentified Steinernema species: T29 from Indonesia and, CF VII from California, USA. The new Steinernema species was depicted as a sister taxon of $S$. scarabaei, a species isolated from scarab beetle larvae in New Jersey, USA (Stock \& Koppenhöfer, 2003). Evolutionary relationships between these two taxa was strongly supported by bootstrap resampling (100\%). Pairwise distance matrix indicated that $S$. hermaphroditum n. sp. and S. scarabaei differed in one character (Table 3 ).

\section{DIAGNOSIS AND RELATIONSHIPS}

Steinernema hermaphroditum n. sp. is characterised by the presence of hermaphrodites in the first adult generation, and the low proportion of males in both adult generations (average: 1 and 5-6\%, respectively (Griffin et al., 2001)). Hermaphrodites of the new species are characterised by having asymmetric vulval lips and the presence of a spermatheca filled with sperm. Males are characterised by the number and distribution of the male genital papillae (21 papillae: seven precloacal pairs, three postcloacal pairs and a single ventral papilla), by having a non-mucronate tail and by the morphology of the spicules and gubernaculum. Third-stage infective juveniles are distinguished by the lateral field pattern (eight equidistant ridges at the midbody level) and the hyaline portion, which occupies $c a 50 \%$ of the tail length.

Steinernema hermaphroditum $\mathrm{n}$. sp. is morphologically most similar to a group of species placed in the feltiaegroup (Table 2) which are characterised by the size of the third-stage infective juveniles (average between 800-1000 $\mu \mathrm{m}$ ), and by the presence of eight ridges at the midbody level (except for S. neocurtillae and S. oregonense Liu \& Berry, 1996). However, the new species can be separated from other members of the feltiae-group by a combination of morphological traits as well as by molecular and biological characteristics.

Infective juveniles of $S$. hermaphroditum n. sp. resemble three species of the feltiae-group viz. S. feltiae (Filipjev, 1934), S. oregonense and S. kraussei (Steiner, 1923) in the morphometric values of all diagnostic features (see Table 2). However, males of the new species can be separated from these three species by the morphology of the spicules and gubernaculum. For example, when compared to $S$. feltiae and $S$. kraussei, the spicules in $S$. hermaphroditum $\mathrm{n}$. $\mathrm{sp}$. have a stouter and more rectangular manubrium and a shorter and wider lamina. Additionally, the gubernaculum in the new species has a longer cuneus than that present in these two species. The spicules in $S$. oregonense have a rhomboid-shaped and longer manubrium than that of $S$. hermaphroditum n. sp. Also, the spicule lamina in $S$. oregonense is narrower and with a more pronounced curvature than that of the new species. In addition to this, males of $S$. hermaphroditum n. sp. lack a tail mucro which is present in $S$. feltiae and $S$. kraussei.

The new species can be separated from S. thanhi Phan, Nguyen \& Moens, 2001 by having infective juveniles with a longer tail (see Table 2) and by the lower mean value of $\mathrm{E} \%$ which is $85 \pm 7$ (76-100) vs $119 \pm 8$ (101- 
Table 3. Pairwise distances (total character differences) between Steinernema spp. based on 28S rDNA sequence data.

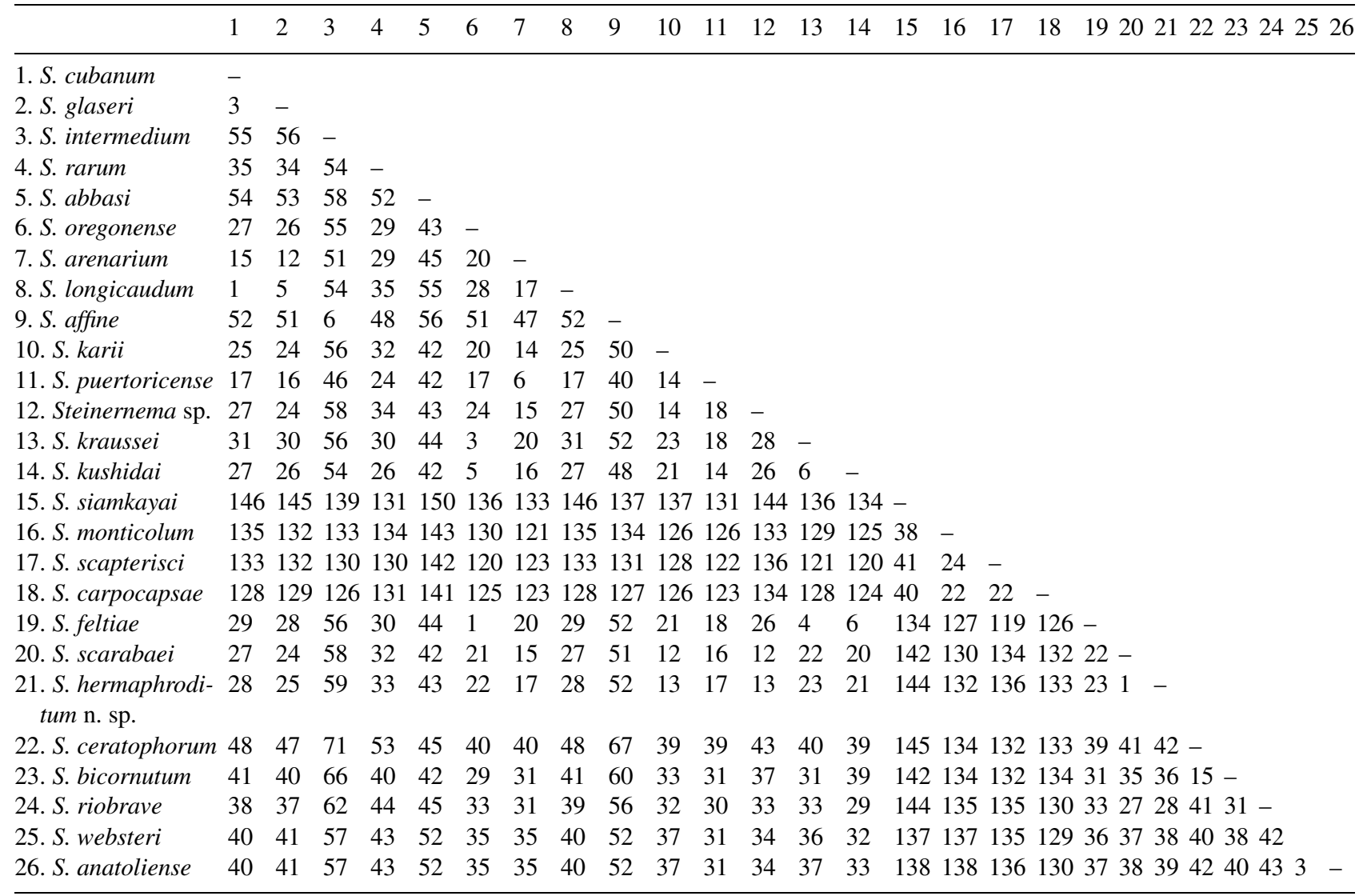

138). In addition to this, females of the new species are characterised by the presence of a digitate and mucronate tail.

Steinernema hermaphroditum n. sp. differs from $S$. neocurtillae by the position of the excretory pore, which is more posteriorly located in the new species, and the values of $\mathrm{D} \%$ and $\mathrm{E} \%$ (see Table 2).

The new species can be separated from $S$. karii in having the excretory pore more anteriorly located and by the mean value of E\% (see Table 2). Moreover, males of the new species differ from $S$. karii by having shorter spicules which are $66 \pm 2$ (65-70) vs $83 \pm 4$ (73-91) $\mu \mathrm{m}$ long.

Steinernema hermaphroditum $\mathrm{n}$. sp. differs from $S$. loci Phan, Nguyen \& Moens, 2001 in having the excretory pore more anteriorly located. Differences are also apparent in the values of $\mathrm{D} \%$ and $\mathrm{E} \%$ (see Table 2).

The new species can be separated from S. scarabaei, a species that was indicated as its sister taxon, by a combination of qualitative and quantitative morphological traits. The third-stage infective juveniles of the new species have the excretory pore opening more anteriorly located in S. scarabaei. Additionally, they differ in the values of $\mathrm{D} \%$ and $\mathrm{E} \%$ (see Table 2). Males of $S$. hermaphroditum n. sp. also differ from $S$. scarabaei by the overall morphology and size of the spicules and gubernaculum and by the value of ratio SW (see Table 2). The papilla-like structures located on the anterior cloacal lip of male S. scarabaei are absent in S. hermaphroditum n. sp.

In addition to these morphological diagnostic traits, RFLP analysis of ITS rDNA showed this species has a restriction profile very similar to $S$. longicaudum (isolate $\mathrm{CB}$ 2B; Griffin et al., 2000). These two species differed only in the profiles of two restriction enzymes, DdeI and HhaI. However, comparison of $28 \mathrm{~S}$ rDNA sequences revealed these two species differ in $28 \mathrm{bp}$, thereby providing further evidence for regarding $S$. hermaphroditum $\mathrm{n}$. sp. as a 
separate species. Moreover, comparison of RFLP profiles of the new species with $S$. scarabaei (depicted as a sister taxon in the 28S rDNA sequence phylogenetic analysis), showed that these two species differ in the patterns of eight (DdeI, HhaI, Hinf I, HpaII, KpnI, PvuII, Sau3AI and $X b a \mathrm{I})$ out of the 17 restriction enzymes use to generate this profile (see Griffin et al., 2000 and Stock and Koppenhöfer, 2003 for complete RFLP profiles).

\section{BIONOMICS}

Steinernema hermaphroditum n. sp. is the first selffertile steinernematid reported (Griffin et al., 2001). The presence of sperm in the reproductive tract of unmated first generation females indicated that the mode of reproduction of this species is by hermaphroditism (Griffin et al., 2001). Males of this nematode are present in both adult generations at a low level. Approximately 1$6 \%$ of the infective juveniles developed into males with the remainder being hermaphrodites. Observations in $G$. mellonella showed that the infective juveniles are able to reach the adult stage in $48-72 \mathrm{~h}$ at $22^{\circ} \mathrm{C}$, with second generation adults appearing in 4-6 days, and infective juveniles emerging 7-9 days after infection.

\section{Discussion}

Over the past few years, concern has been raised regarding the conservative nature of the genes considered for species barcodes (Floyd et al., 2002). Yet correspondence between the molecular operational taxonomic units (MOTU) and nominal species (Floyd et al., 2002) or morphospecies (Powers, pers. comm.) is worth mentioning in nematology. With respect to Steinernematidae, sequence data of the LSU have been used to assess phylogenetic relationships among Steinernema species. This has proved to be a suitable and informative region for interpreting evolutionary relationships among Steinernema spp. (Stock et al., 2001; Stock \& Reid, 2004). Study of this region is also considered to be an effective and reliable approach for delimitation of taxa in Steinernema, as well as for diagnostic purposes (Stock et al., 2001; Stock \& Koppenhöfer, 2003).

Recently, other nuclear genes, such as the internal transcribed spacer region (ITS) of rDNA, have been considered when assessing phylogenetic relationships and delimiting taxa in Steinernema (Nguyen et al., 2001; Phan et al., 2001a, b). In spite of these efforts, the ITS region seems to be only useful for resolving relationships among closely related Steinernema species, and is perhaps too variable to reliably infer relationships among all species in the genus (Stock et al., 2001; Stock \& Reid, 2004). Moreover, difficulties in alignment for phylogenetic analysis with this region, and the potential of individual heteroplasmy in some nematode species (Powers et al., 1997) can lead to misdiagnosis in species of hybridogenetic origin (Hugall et al., 1999). Therefore, care should be taken when considering this region for delimitation of taxa in Steinernema.

An understanding of the variation at the intraspecific level, i.e., considering population level sampling, should be taken into account in order to clearly define the exclusive and fixed nature of autapomorphies between species in this genus. Furthermore, it should be borne in mind that acquisition of multiple data sets from independent genesis is necessary to provide more robust and testable hypotheses of the evolutionary relationships in Steinernema.

\section{Acknowledgement}

This work was supported in part by a USDA-HatchARZT-136816-H-05-124 grant to S.P. Stock.

\section{References}

Amarasinghe, L.D., Hominick, W.M., Briscoe, B.R. \& REID, A.P. (1994). Occurrence and distribution of entomopathogenic nematodes in Sri Lanka. Journal of Helminthology 68, 277-286.

Bedding, R.A. \& AkHuRst, R.J. (1975). A simple technique for detection of insect parasitic rhabditid nematodes in soil. Nematologica 21, 109-110.

Courtney, W.D., Polley, D. \& Miller, V.L. (1955). TAF, an improved fixative in nematode techniques. Plant Disease Reporter 39, 570-571.

Floyd, R., Abebe, E., Papert, A. \& Blaxter, M. (2002). Molecular barcodes for soil nematodes identification. Molecular Ecology 11, 839-850.

GAUGLER, R. \& KAYA, H.K. (1990). Entomopathogenic nematodes in biological control. Boca Raton, FL, USA, CRC Press, 365 pp.

Griffin, C.T., Chaerani, R., Fallon, D., Reid, A.P. \& DOWNES, M.J. (2000). Occurrence and distribution of the entomopathogenic nematodes Steinernema spp. and Heterorhabditis indica in Indonesia. Journal of Helminthology 74, 143-150.

GrifFin, C.T., O'Callaghan, K.M. \& DiX, I. (2001). A self-fertile species of Steinernema from Indonesia: further 
evidence of convergent evolution among entomopathogenic nematodes? Parasitology 122, 181-186.

Hominick, W.M. (2002). Biogeography. In: Gaugler, R. (Ed.). Entomopathogenic nematology. Wallingford, UK, CABI Publishing, pp. 115-143.

Hominick, W.M., Briscoe, B.R., Del Pino, F.G., Heng, J.A., Hunt, D.J., Kozodoy, E., MrÁčeK, Z., NguYen, K.B., Reid, A.P., SPIRIdonov, S.E., Stock, P., Sturhan, D., Waturu, C. \& Yoshida, M. (1997). Biosystematics of entomopathogenic nematodes: current status, protocols and definitions. Journal of Helminthology 71, 271-298.

Hugall, A., Stanton, J. \& Moritz, C. (1999). Reticulate evolution and the origins of ribosomal internal transcribed spacer diversity in apomictic Meloidogyne. Molecular Biology and Evolution 16, 157-164.

KAYA, H.K. \& GAUGLER, R. (1993). Entomopathogenic nematodes. Annual Review of Entomology 38, 181-206.

KAYA, H.K. \& STOCK, S.P. (1997). Techniques in insect nematology. In: Lacey, L.A. (Ed.). Techniques in insect pathology. London, UK, Academic Press, pp. 281-324.

LIU, J. \& BERRY, R.E. (1996). Steinernema oregonensis n. sp. (Rhabditida: Steinernematidae) from Oregon, USA. Fundamental and Applied Nematology 19, 375-380.

Luc, P.V., NGuyen, K.B., Reid, A.P. \& Spiridonov, S.E. (2000). Steinernema tami n. sp. (Rhabditida: Steinernematidae) from Cat Tien forest, Vietnam. Russian Journal of $\mathrm{Ne}$ matology 8, 33-43.

Masson, J.M., RAZAK, A.R. \& Wright, D.J. (1996). The recovery of entomopathogenic nematodes from selected areas within Peninsular Malaysia. Journal of Helminthology 70, 303-307.

MráČeK, Z., Hernandez, E.A. \& Boemare, N.E. (1994). Steinernema cubana sp. n. (Nematoda: Rhabditida: Steinernematidae) and the preliminary characterisation of its associated bacterium. Journal of Invertebrate Pathology 64, 123129.

Nguyen, K.B. \& Smart JR., G.C. (1992). Addendum to the morphology of Steinernema scapterisci. Journal of Nematology 24, 478-481.

Nguyen, N.C., Nguyen, V.T., Phan, K.L. \& Lai, P.H. (1999). Preliminary surveys on natural occurrence of entomopathogenic nematodes in Vietnam. Biology 21, 94-100.

Nguyen, K.B., Maruniak, J. \& Adams, J.B. (2001). Diagnostic and phylogenetic utility of the rDNA internal transcribed spacer sequences of Steinernema. Journal of Nematology 33, 73-82.
Phan, K.L., Nguyen, N.C. \& Moens, M. (2001a). Steinernema loci $\mathrm{sp} . \mathrm{n}$. and Steinernema thanhi sp. n. (Rhabditida: Steinernematidae) from Vietnam. Nematology 3, 503-514.

Phan, K.L., NGUyen, N.C. \& MOENS, M. (2001b). Steinernema sangi sp. n. (Rhabditida: Steinernematidae) from Vietnam. Russian Journal of Nematology 9, 1-7.

POINAR JR., G.O. (1990). Entomopathogenic nematodes in biological control. In: Gaugler, R. and Kaya, K.H. (Eds). Taxonomy and biology of Steinernematidae and Heterorhabditidae. Boca Raton, FL, USA, CRC Press, pp. 23-74.

Powers, T.O., Todd, T.C., Burnell, A.M., Murray, P.C.B., Fleming, C.C., Szalanski, A.L., Adams, B.A. \& HARRIS, T.S. (1997). The rDNA internal transcribed spacer region as a taxonomic marker for nematodes. Journal of Nematology 29, 441-450.

SEINHORST, J.W. (1959). A rapid method for the transfer of nematodes from fixative to anhydrous glycerin. Nematologica 4, 67-69.

SHEN, C.P. \& WANG, G.H. (1992). [Description of an entomopathogenic nematode, Steinernema longicaudum sp. nov. and its application.] In: Proceedings of the XIX International Congress of Entomology, Beijing, China, 28-June-4 July 1992 pp. 220-231.

Stock, S.P. \& KoppenhöFer, A.M. (2003). Steinernema scarabaei n. sp. (Rhabditida: Steinernematidae), a natural pathogen of scarab beetle larvae (Coleoptera: Scarabaeidae) from New Jersey, USA. Nematology 5, 191-204.

STOCK, S.P. \& REID, A.P. (2004). Biosystematics of entomopathogenic nematodes (Steinernematidae, Heterorhabditidae): current status and future directions. In: Cook, R. \& Hunt, D.J. (Eds). Proceedings of the Fourth International Congress of Nematology, 8-13 June 2002, Tenerife, Spain. Nematology Monographs and Perspectives 2, 435-446.

Stock, S.P., SomsooK, V. \& ReID, A.P. (1998). Steinernema siamkayai (Rhabditida: Steinernematidae), an entomopathogenic nematode from Thailand. Systematic Parasitology 41, 105-113.

StOCK, S.P., CAMPbell, J.F. \& NAdleR, S.A. (2001). Phylogeny of Steinernema Travassos, 1927 (Cephalobina: Steinernematidae) inferred from ribosomal DNA sequences and morphological characters. Journal of Parasitology 87, 877-889.

SWOFFORD, D.L. (2001). PAUP*. Phylogenetic analysis using parsimony (* and other methods), Version 4. Sunderland, MA, USA, Sinauer Associates, 257 pp.

Waturu, C.N., Hunt, D.J. \& ReID, A.P. (1997). Steinernema karii sp. n. (Nematoda: Steinernematidae), a new entomopathogenic nematode from Kenya. International Journal of Nematology 7, 68-75. 